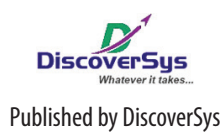

Published by DiscoverSys

\section{Incidence of dispensing errors before and after root cause analysis at Sanglah General Hospital, Denpasar}

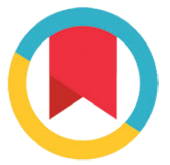

CrossMark

\author{
Ni Kadek Erna Erawati, ${ }^{*}$ I Made Ady Wirawan, ${ }^{2}$ Cokorda Bagus Jaya Lesmana ${ }^{3}$
}

\section{ABSTRACT}

Background and purpose: Drug dispensing errors have a major impact on the incidence of medication errors, and can be very dangerous to patients and affect the quality of care. Root cause analysis (RCA) is an approach to prevent dispensing errors by identifying the root of the problem, make efforts to improve comprehensively across departments so that incidence of dispensing errors are not repeated. The purpose of this study is to determine the differences in the incidence of dispensing errors before and after the RCA.

Methods: This is a descriptive study by calculating the incidence of dispensing errors before and after the RCA, conducted in four inpatient wards at Sanglah Hospital Denpasar. Dispensing errors were categorized into ten types namely errors in drug's identity, name, dosage, number of drugs, absence of high alert labels, incorrect drug preparations, incorrect strength, expired drugs, incorrect place of delivery and incorrect instructions. In February and April 2018 there were 80 and 40 dispensing errors which met the study criteria, respectively.

Results: Crude incidence of dispensing errors before and after RCA were 2.54 per 1000 ( $95 \% \mathrm{Cl}: 1.98-3.10)$ and 1.26 per 1000 (95\%Cl:0.87-1.65), respectively. The decrease in dispensing error after RCA was $50.39 \%$. The ratio of dispensing error incidence rates after and before the RCA is 0.49 . Significant decrease in the incidence of dispensing errors was only found in drug identity errors of 1.27 per $1000(95 \% \mathrm{Cl}: 0.88-1.66)$ before an RCA and 0.06 per 1000 (95\%Cl: $-0.03-0.15$ ) after RCA, or decreased by $95.27 \%$ and there was no significant decrease in other dispensing errors. Conclusion: The decrease of dispensing errors after the RCA was only found in the medication identity error and not found in the other dispensing errors. Direct observation and intensive supervision are needed in order to accurately calculate and reduce the incidence of dispensing errors.
${ }^{1}$ Sanglah General Hospital, ${ }^{2}$ Department of Public Health and Preventive Medicine, Udayana University,

${ }^{3}$ Department of Psychiatry, Faculty of Medicine, Udayana University

${ }^{*}$ Correspondence to:

Ni Kadek Erna Erawati, Sanglah

General Hospital,

ernaerawati112@gmail.com
Keywords: Root cause analysis, dispensing errors, incidence

Cite This Article: Erawati, N.K.E., Wirawan, I.M.A., Lesmana, C.B.J. 2019. Incidence of dispensing errors before and after root cause analysis at Sanglah General Hospital, Denpasar. Public Health and Preventive Medicine Archive 7(2): 110-113. D0I:10.15562/phpma.v7i2.213

\section{INTRODUCTION}

Dispensing errors are incorrect preparation of drugs and not in accordance with doctor's orders. ${ }^{1}$ Dispensing errors were developed by Beso which consisted of two types namely content errors and labeling errors. ${ }^{2}$ Content errors include expired drugs and errors in medication, drug strength, medication dose, number of drugs (excess or deficiency) and medication type. Labeling errors include errors in patient names, medication name, drug strength, frequency, dosage, date, administration instructions, label and incomplete information. ${ }^{2}$

Dispensing errors can lead to errors in drug delivery that can have a negative impact on patients ranging from mild to fatal effects. ${ }^{3}$ In addition, dispensing errors can also cause complaints from consumers, thereby impacting upon the image of the hospital and reducing the quality of patient care. ${ }^{4}$ Dispensing errors in the United States were reported at $1.6 \%,{ }^{5}$ in India as much as $4.8 \%$, where the highest errors were found in drug name with a proportion of $43.1 \%$ of the total dispensing errors. ${ }^{6}$ Dispensing errors at
Fatmawati Hospital Jakarta were found as much as $62.1 \%$ consisting of drug etiquette errors at $61.0 \%$ and errors in the number of drugs at $1.1 \%{ }^{7}$ The incidence of dispensing errors in Sanglah Hospital Denpasar was reported to increase by 2.6 per thousand drug dispensing event in May 2018, 2.98 in June, 2.95 in July and 3.9 in August. Dispensing errors are related to several variables, namely medication management procedure, work environment, dispensing equipment, health workers and patient factors. ${ }^{1,8}$

The root cause analysis (RCA) is an approach that is used to find root causes, plan and carry out comprehensive and cross-departmental responses. ${ }^{9}$ The RCA has been widely used to look for root problems in various fields, such as the management of regional property, ${ }^{10}$ work accident problems, ${ }^{11}$ tuberculosis situation analysis, ${ }^{12}$ non-value added activities, ${ }^{13}$ complications related procedures, ${ }^{14}$ medication errors ${ }^{15}$ and dispensing errors. ${ }^{16}$

Sanglah General Hospital Denpasar applies the RCA to find some of the root problems that occur, 
including dispensing errors, and formulate solutions. The results of previous studies on dispensing errors and their corrections after RCA have not been widely published in Indonesia. This study aims to determine the incidence of dispensing errors before and after an RCA at Sanglah Hospital Denpasar.

\section{METHODS}

The design of this study was descriptive by calculating the incidence of dispensing errors before and after the RCA. The study was conducted at Sanglah Hospital Denpasar that has 765 beds and the only type A hospital for the provinces of Bali, West Nusa Tenggara and East Nusa Tenggara. Sanglah Hospital has been nationally accredited in 2014 and 2017 and accredited by Joint Commission International (JCI) in 2013 and 2016.

Sanglah Hospital has implemented electronic prescribing for inpatients since 2016. RCA on drug dispensing was carried out in January 2014 and March 2018, and after that an effort was made which included three aspects as follows. First, education about pharmaceutical service policy and revitalization of the existing dispensing standard operational procedures. Second, the revision of dispensing implementation and third, logistics procurement which includes identity and high alert labels and improvement of facilities at pharmacies.

Data collection was conducted in July 2019. Data which collected were the dispensing and the dispensing errors occurred one month before the second RCA (March 2018) and after the correction efforts in April 2018. The data source was the report on dispensing errors for inpatients available in the hospital information system of 31,451 dispensing events before an RCA and 31,700 after an RCA. Data collected includes errors in drug's identity, name, dosage, number of drugs, absence of high alert labels, incorrect drug preparations, incorrect strength, expired drugs, incorrect place of delivery and incorrect instructions. Data not included in the analysis are dispensing in the form of liquids and medical devices with the consideration that dosage forms, strengths and dosages cannot be distinguished.
Data analysis was performed descriptively through calculating the incidence of dispensing errors. The number of dispensing errors was divided by the number of dispensing. Incidences of dispensing errors before and after the RCA were compared in order to get the incidence ratio or relative risk (RR). The difference of incidence before and after the RCA is calculated to get attributable risk (AR). The crude incidence rate is calculated if one type of error is found out of the ten errors studied. In addition, the specific incidence by type of error was also calculated. The confidence interval of incidence rate before and after the RCA is determined by $95 \%$ significance level.

This study has been approved by the Human Research Ethics Committee of Udayana University/Sanglah Hospital Denpasar on 11 June 2019.

\section{RESULTS}

Table 1 presents the crude incidence of dispensing errors before and after the RCAs, that are 2.54 per 1000 dispensing (95\%CI: $1.98-3.10)$ and 1.26 per 1000 dispensing (95\%CI: 0.87-1.65), respectively. It can be seen that the decrease in dispensing error after RCA is $50.39 \%$. The ratio of dispensing error incidence rates after and before the RCA is 0.49 .

Table 2 presents the specific incidence by types of dispensing errors. Significant decrease in the incidence of dispensing errors was only found in drug identity errors of 1.27 per 1000 (95\%CI: 0.88-1.66) before an RCA and 0.06 per 1000 (95\%CI: -0.03-0.15) after the RCA, or reduced by $95.27 \%$. Errors in drug names were found to be higher after than before RCA but statistically not significant, which were 0.34 per 1000 (95\%CI: 0.14-0.54) and 0.25 per 1000 (95\%CI: 0.08-0.42) respectively.

Table 2 also shows a decrease in dispensing errors after RCA, namely in drug dosage errors, number of drugs, high alert labeling, drug strength and drug preparation, but not statistically significant. No errors were found regarding expired drugs, misplaced delivery and instructions both before and after the RCA.

Table 1 Crude incidence of dispensing error before and after RCA

\begin{tabular}{lccccccc}
\hline & \multicolumn{7}{c}{ Drug dispensing } \\
\cline { 2 - 7 } Time period & $\begin{array}{c}\text { Number of } \\
\text { errors }\end{array}$ & $\begin{array}{c}\text { Number of } \\
\text { dispensing }\end{array}$ & $\begin{array}{c}\text { Errors per } \mathbf{1 0 0 0} \\
\text { dispensing }\end{array}$ & $\begin{array}{c}\mathbf{9 5 \% C l} \\
\text { incidence }\end{array}$ & AR (\%) & RR & p \\
\hline Before & 80 & 31,451 & 2.54 & $1.98-3.10$ & 50.39 & 0.49 & 0.001 \\
After & 40 & 31,700 & 1.26 & $0.87-1.65$ & & \\
\hline
\end{tabular}


Table 2 Specific incidence by type of dispensing error

\begin{tabular}{|c|c|c|c|c|c|c|c|c|c|}
\hline \multirow[b]{2}{*}{ Type of Error } & \multicolumn{3}{|c|}{ Before } & \multicolumn{3}{|c|}{ After } & \multirow[b]{2}{*}{ AR (\%) } & \multirow[b]{2}{*}{$\mathbf{R R}$} & \multirow[b]{2}{*}{$\mathbf{p}$} \\
\hline & $\begin{array}{c}\text { Number } \\
\text { of errors } \\
(\mathrm{N}=31,451)\end{array}$ & $\begin{array}{c}\text { Incidence } \\
\text { per } 1000 \\
\text { dispensing }\end{array}$ & $95 \% \mathrm{Cl}$ & $\begin{array}{c}\text { Number } \\
\text { of errors } \\
(\mathrm{N}=31,700)\end{array}$ & $\begin{array}{l}\text { Incidence } \\
\text { per } 1000 \\
\text { dispensing }\end{array}$ & $95 \% \mathrm{Cl}$ & & & \\
\hline Drug's identity & 40 & 1.27 & $0.88-1.66$ & 2 & 0.06 & $-0.03-0.15$ & 95.27 & 0.05 & $<0.01$ \\
\hline Drug's name & 8 & 0.25 & $0.08-0.42$ & 11 & 0.34 & $0.14-0.54$ & -36.0 & 1.36 & 0.26 \\
\hline Dosage & 2 & 0.06 & $-0.03-0.15$ & 1 & 0.03 & $-0.03-0.09$ & 50.0 & 0.5 & 0.56 \\
\hline Number of drugs & 3 & 0.09 & $-0.06-0.19$ & 0 & 0 & $0.00-0.00$ & 100.0 & 0 & 0.82 \\
\hline Absence of high alert label & 19 & 0.60 & $0.33-0.87$ & 19 & 0.59 & $0.32-0.86$ & 1.66 & 0.98 & 0.98 \\
\hline Incorrect drug preparation & 5 & 0.15 & $0.01-0.29$ & 5 & 0.15 & $0.01-0.29$ & 0 & 1 & 0.73 \\
\hline Incorrect strength & 3 & 0.09 & $-0.01-0.19$ & 2 & 0.06 & $0.03-0.15$ & 33.33 & 0.66 & 0.65 \\
\hline Expired medicine & 0 & 0 & 0 & 0 & 0 & $0.00-0.00$ & 0 & 0 & 1.0 \\
\hline Incorrect delivery place & 0 & 0 & 0 & 0 & 0 & $0.00-0.00$ & 0 & 0 & 1.0 \\
\hline Incorrect instructions & 0 & 0 & 0 & 0 & 0 & $0.00-0.00$ & 0 & 0 & 1.0 \\
\hline
\end{tabular}

\section{DISCUSSION}

Our study shows that the crude incidence of dispensing errors before and after the RCAs, are 2.54 per 1000 dispensing and 1.26 per 1000 dispensing respectively, resulted in a $50.39 \%$ decrease in drug dispensing errors. However, a significant decrease in dispensing errors only occurred in drug identity errors, and no significant decrease was found in terms of medication dosage, number of drugs, high alert labeling, strength of drugs and drug preparation. These findings indicate that RCA was not effective to reduce these errors in this study setting. Significant reduction in drug identity errors is likely due to the continuous provision of drug identity labels after RCA and double checking before the drugs are sent to the treatment room.

The incidence of dispensing errors at Sanglah Hospital is quite low when compared to other regions or countries. ${ }^{5-7}$ The dispensing errors are likely underreported because dispensing error data was obtained from the hospital information system and the awareness of staff to report and upload the errors remains low. In addition, it is likely that there are no particular staff appointed to conduct monitoring and reporting of the dispensing errors. A study conducted in India ${ }^{6}$ shows that data collection of dispensing errors was carried out by a designated nurse specifically to monitor inpatient prescriptions and subsequently reported the dispensing error to the dispensary. In the Indian study, there was a $4.8 \%$ dispensing errors with $43.1 \%$ of them in the form of drug's name errors. Another study in six cities in The United States reported that dispensing errors were calculated by assigning 50 pharmacists to report dispensing errors at 50 pharmacies and found that dispensing errors were $1.6 \%{ }^{5}$
The low dispensing error in our study is also likely due to the fact that the drug dispensing system that has been carried out quite well and has been implementing vigilance against drugs that look similar and pronunciation similar to Tall Man Lettering, using electronic prescribing, double checking systems and drug labeling. The pharmaceutical depot may also examine the expiration date of ordered drugs and prioritize dispensing of drugs with the closest expiration date. In addition, the assignment of pharmaceutical workers with greater numbers during peak hours allows for more careful dispensing due to light workload. This is similar with other studies that show that dispensing errors are related to a comfortable and spacious work environment, employee health, good medication management and dispensing tools. ${ }^{1}$ However, this is less likely based on the evidence that the dispensing error in other settings and countries was much higher. $^{5-7}$

The limitation of our study is that the data obtained from dispensing errors entered into the system are reported in hospitals and not from direct observation of dispensing errors at pharmacies. Another limitation is that this study was only carried out in one type of referral hospital, hence cannot be generalized in a broader context with different settings.

\section{CONCLUSION}

The incidence of dispensing errors was found to be quite low which is likely due to the calculation of the error not being done directly but on reports uploaded to the system at the hospital. The decrease in dispensing errors after RCA only occurs in drug identity errors and there is no decrease in other dispensing errors. To obtain more accurate information on 
dispensing errors, it is necessary to calculate dispensing errors directly at the pharmacy. In addition, more intensive supervision is needed in implementing RCA to reduce other dispensing errors.

\section{ACKNOWLEDGMENTS}

We would like to thank the Director of Sanglah Hospital Denpasar for providing access to the dispensing errors data in the hospital information system.

\section{REFERENCES}

1. Siregar CJP, Kumolosari E. Farmasi klinik: Teori dan penerapan [Clinical pharmacy: Theory and application]. $1^{\text {st }}$ edition. Sari LA, editor. Jakarta: EGC; 2006. 172

2. Beso A, Franklin BD, Barber N. The frequency and potential causes of dispensing error in a hospital pharmacy. Pharmacy World and Science. 2005;27(3):182-190.

3. Cheung KC, Van Den Bemt PMLA, Bouvy ML, Wensing M, De Smet PAGM. Medication incidents related to automated dose dispensing in community pharmacies and hospitals-a reporting system study. PLoS One. 2014;9(7):1-9.

4. The Committee of Hospital Patient Safety. Pedoman pelaporan insiden keselamatan pasien [Patient safety incident report]. Jakarta: The Committee of Hospital Patient Safety; 2015.

5. Flynn EA, Barker KN, Berger BA, Lloyd KB, Brackett PD. Dispensing errors and counseling quality in 100 pharmacies. Journal of the American Pharmacists Association. 2009;49(2):171-182.

6. Sekhar SM, Mathew MA, Abraham S, Anand A, Sasidharan S. Study on dispensing errors of inpatient prescriptions in a tertiary care hospital. Der Pharmacia Sinica. 2011;2(1):14-8.

7. Susanti I. Identifikasi medication error pada fase prescribing, transcribing, dan dispensing di depo rawat inap penyakit dalam Gedung Teratai, Instalasi Farmasi RSUP Fatmawati periode 2013 (Skripsi) [Identification of medication errors in prescribing, transcribing and dispensing phases at the internal medicine inpatient pharmacy, Teratai Building, Department of Pharmacy, Fatmawati General Hospital (Undergraduate thesis)]. UIN Syarif Hidayatullah. Jakarta; 2013.
8. Rikomah SE. Farmasi klinik [Clinical pharmacy]. $1^{\text {st }}$ edition. Yogyakarta: Deepublish; 2014.

9. Kellogg KM, Hettinger Z, Shah M, Wears RL, Sellers CR, Squires M, et al. Our current approach to root cause analysis: Is it contributing to our failure to improve patient safety?. BMJ Quality \& Safety. 2017;26(5):381-387.

10. Pebriansya T. Penerapan root cause analysis dalam menyelesaikan permasalahan pengelolaan barang milik daerah pada pemerintah daerah di Provinsi Bengkulu (Skripsi) [The implementation of root cause analysis in solving the issues of local government facilities management in Bengkulu Province [Undergraduate thesis]. Lampung University. Bandar Lampung; 2017.

11. Kuswardana A, Mayangsari NE, Amrullah HN. Analisis penyebab kecelakaan kerja menggunakan Metode RCA (Fishbone Diagram Method and 5-Why Analysis) di PT. PAL Indonesia [The work accidents causes analysis using RCA Method (Diagram Method and 5-Why Analysis) at the company of PAL Indonesia]. 1st Proceeding Conference on Safety Engineering and Its Application. 2017;1(1):141-146.

12. Rahayu SLS. Analisis situasi tuberkulosis di Provinsi DKI Jakarta dengan metode root cause analysis (RCA) [Situation analysis of tuberculosis in Jakarta Province using root cause analysis (RCA)]. Prosiding Kolokium Doktor dan Seminar Hasil Penelitian Hibah. 2016;1(1):277-290.

13. Syawalluddin MW. Pendekatan lean thinking dengan menggunakan metode root cause analysis untuk mengurangi non value added activities [Lean thinking approach using the root cause analysis to reduce the non value added activities]. Jurnal PASTI. 2014;VIII(2):236-250.

14. Kellogg KM, Hettinger Z, Shah M, Wears RL, Sellers CR, Squires M, et al. Our current approach to root cause analysis: is it contributing to our failure to improve patient safety?. BMJ Quality \& Safety. 2017; 26: 381-387.

15. Solanki ND, Shah C. Root cause analysis of medication errors at a multi-specialty hospital in Western India. International Journal of Basic \& Clinical Pharmacology. 2013;2(6):819-823.

16. Campmans Z, van Rhijn A, Dull RM, Santen-Reestman J, Taxis K, Borgsteede SD. Preventing dispensing errors by alerting for drug confusions in the pharmacy information system-A survey of users. PLoS One. 2018;13(5):1-11.

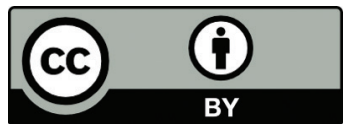

This work is licensed under a Creative Commons Attribution 